\title{
MEASURING OCCUPATIONAL SELF-EFFICACY: A CULINARY STUDENTS' COOKING PERFORMANCE PERSPECTIVE
}

\author{
Tuatul Mahfud ${ }^{1, ~ *}$, Mutiara Nugraheni ${ }^{2}$, Pardjono $^{3}$, Badraningsih Lastariwati ${ }^{4}$ \\ ${ }^{1}$ Balikpapan State Polytechnic, J1.Soekarno Hatta KM 8, Balikpapan, Indonesia \\ ${ }^{2,3,4}$ Faculty of Engineering, Universitas Negeri Yogyakarta, Karangmalang, Yogyakarta 55281, Indonesia \\ E-mail: tuatul.mahfud@poltekba.ac.id * \\ *Corresponding Author
}

\begin{abstract}
Occupational self-efficacy is believed to be an essential factor for optimizing mastery of cooking competencies for culinary students. Although there have been many studies examining the importance of selfefficacy, there are still limited studies that discuss how to measure the self-efficacy of cooking abilities for culinary vocational students. This study aims to develop and test the validity of the self-efficacy cooking skills questionnaire. This study involved 329 culinary students in the Special Region of Yogyakarta, Indonesia. Data analysis uses Confirmatory Factor Analysis (CFA) to test the validity and reliability. The results of the study revealed that the occupational self-efficacy of cooking performance could be explained by four indicators, namely the enactive experience, model experience, social persuasion, and emotional conditions. This questionnaire has 16 items consisting of 4 items in each indicator. The results of this study have implications for industry and education practitioners to evaluate the achievement of mastery of students 'and chefs' cooking skills.
\end{abstract}

Keywords: CFA, chef, cooking performance, occupational, self-efficacy

\section{INTRODUCTION}

The industry now understands that business development, aside from paying attention to tangible capital such as data and physical resources, also needs to pay attention to intangible human capital such as positive human psychology. In principle, individual development of psychological capital is shown in positive mental status. One form of psychological capital that needs to be developed is self-efficacy [1]. Bandura [2] introduced the term self-efficacy in the context of social learning. $\mathrm{He}$ then incorporated this psychological construction into his social cognitive theory. In his opinion, Bandura [3] proposes a learning model in which cognition, behavior, and environment influence each other. Individuals process information from each of these elements to form their thoughts and behavior.

In positive psychology, self-efficacy is a construction that is synonymous with selfconfidence and refers to a person's judgment about his ability to perform a task at a certain level of performance [4], [5] and makes sense beyond the real skills that lead to the job complete tasks [6]. Similarly, Bandura et al. [7] revealed that self-efficacy is a personal belief about their level of competence in certain situations. Stajkovic \& Luthans [8] define beliefs (self-efficacy) as individual beliefs about their ability to mobilize the motivation, cognitive resources, and actions needed to carry out specific tasks in certain contexts successfully. Besides, self-confidence is a positive psychological capital capacity and has been shown to have a strong positive relationship with work-related performance [9]. Individuals with low levels of self-efficacy will have negative thoughts and regard task demands as a threat that is not challenging and therefore sets small goals for themselves [10]. From this perspective, individuals have high self-efficacy when they believe their skill level meets or exceeds their job demands.

Self-efficacy is not a general trait but related to specific tasks and situations [3]. In the context of work, self-efficacy is known as occupational self-efficacy, which can be defined as a person's perception of his ability to carry out his work duties effectively [11]. There have been 
many studies discussing the importance of occupational self-efficacy in the context of the world of work [12]-[16].

A study conducted by Paggi \& Jopp [17] revealed that occupational self-efficacy predicts job satisfaction and life satisfaction. Occupational self-efficacy has a significant role in performance [14]. Besides, occupational selfefficacy has been positively associated with professional performance, skills development, work involvement, positive attitude towards the organization, job satisfaction [11], [18], and positive influence at work [19]. On the other hand, a low level of occupational self-efficacy is associated with negative work outcomes, such as burnout [20], [21] and negative effects related to work [22].

In the chef profession, strengthening selfefficacy of the ability to do cooking tasks is very necessary. Chefs who have confidence in their abilities tend to approach the work of a chef. Therefore, the provision of occupational selfefficacy as a chef must begin from the time the individual is in school. In this context, the culinary vocational school has a vital role in preparing prospective professional chefs. Measuring occupational self-efficacy refers to measuring self-efficacy in general. Self-efficacy can be conceptualized and measured through four sources of information that contribute to the development of self-efficacy. These sources are: (a) enactive mastery experience or enacting mastery experience, (b) experience models or peer observations and other role models (vicarious experience), (c) verbal/social persuasion or encouragement from others (verbal/social persuasion), and (d) physiological and affective states or physical/emotional conditions [2], [3], [23].

Enactive mastery experience refers to the confidence gained in a person's past success or failure in an activity. Empirically, the most reliable source of self-efficacy information is usually an achievement that has been experienced and is evident [2], [24]. According to Bandura [2], every success will build one's trust, and conversely, every failure will weaken it. Model experience (vicarious experience) refers to a person's beliefs that are obtained through observing other people for their successes or failures [25]. Observing others who are successful can give confidence to their ability to do the same task [2]. Modeling experiences are more effective when individuals recognize the same relationship between their skills and the capabilities of the model. The higher the assumed similarity between the model and himself, the more persuasive the successes and failures of the model [9]. Besides, verbal/social persuasion is the assessment and opinion of others and their influence on the individual decision-making process [2]. Verbal persuasion is easy to achieve but not as persistent or as effective as providing opportunities with a gradual increase in challenges and risks [2]. Inappropriate, excessive, or superficial praise may be ineffective or even detrimental to students' intrinsic motivation and performance progress [26]. Praise can be meaningful and helpful when the compliment is proportional, specific, authentic, and based on performance that is genuinely praised [27]. While the physiological/emotional state refers to the level of physical arousal and emotional mood of the individual. Perceived ability is influenced by our awareness of the physical and emotional reactions of the body to certain situations [2]. Perceptions of self-efficacy can be improved by developing physical strength, reducing stress, developing positive thinking, and increasing mental interpretation of the state of the body [28].

Referring to the broad database, then in the context of this study, the self-efficacy of a chef occupation is one's self-confidence in his ability to do work in a chef's profession. Several studies conducted by the experts above indicate that it is essential to build and develop occupational selfefficacy for students in vocational schools as their capital in preparing themselves to be skilled in the chosen field of expertise. Although there have been many studies that discuss the importance of self-efficacy, there are still limited studies that address occupational self-efficacy in 
the area of cooking. This study aims to develop and test an occupational self-efficacy questionnaire on cooking ability.

\section{METHOD}

This study involved culinary students in Yogyakarta-Indonesia as respondents. Three hundred ninety-two students had filled out a questionnaire from a total population of 950 culinary vocational students in Yogyakarta (see Table 1).

Table 1. Background of Participants $(\mathrm{N}=392)$

\begin{tabular}{clcc}
\hline Attribute & \multicolumn{1}{c}{ Categories } & $\mathrm{N}$ & $\%$ \\
\hline \multirow{3}{*}{ Gender } & Male & 46 & 11.7 \\
& Female & 346 & 88.3 \\
& Culinary School A & 50 & 12.8 \\
& Culinary School B & 52 & 13.3 \\
& Culinary School C & 35 & 8.9 \\
& Culinary School D & 23 & 5.9 \\
& Culinary School E & 39 & 9.9 \\
& Culinary School F & 78 & 19.9 \\
& Culinary School G & 115 & 29.3 \\
\hline
\end{tabular}

Data on occupational self-efficacy of cooking ability was revealed with the Occupational Self-Efficacy Questionnaire (OSEQ) on Cooking Ability, developed and adapted from the Zelenak instrument [29]. The self-efficacy of chef occupations for vocational students is explained through several indicators consisting of enactive experiences, model experiences, verbal or social persuasion, and emotional conditions. Furthermore, each indicator is broken down into smaller components. These components form the questions in the Occupational Self-Efficiency Questionnaire on cooking skills. This questionnaire was developed to look at the indicators of self-occupational efficacy of chefs for culinary students, which included active experiences, model experiences, verbal or social persuasion, and emotional states. This questionnaire uses a Likert scale with five alternative answers consisting of strongly agree, agree, somewhat agree, disagree, and disagree. The weight of the scoring used, which includes strongly agree $=5$, agree $=4$, neutral $=3$, disagree $=2$, strongly disagree $=1$.

The validity testing of the OSEQ questionnaire consisted of three stages. In the first stage, the content validity of the OSEQ was determined through the expert validation process. This validation was carried out by involving three experts consisting of experts in psychometric, culinary education, and vocational education. Each expert was given a set of questionnaires to assess the appropriateness and relevance of the instrument items to the study indicators. The relevancy scale used in questionnaire was a five-point scales consisting of "highly irrelevant" is 1, "irrelevant" is 2, "quite relevant" is 3, "relevant" is 4 , "very relevant" is 5 respectively. The data were analyzed using Aiken V [30].

In the second stage, OSEQ pilot testing using small samples. The number of samples used was 59 respondents. We used the Pearson Correlation Analysis at 5\% significance to test item validity. Items are considered valid if they have a significant value below 0.05. Meanwhile, we used Cronbach's Alpha analysis to test the reliability of the OSEQ questionnaire. Items are considered reliable if they have a Cronbach's Alpha value above 0.7 [31]. Data analysis used SPSS 19.0 for Windows Evaluation Version software.

In the final stage, the construct validity test of the OSEQ questionnaire used confirmatory factor analysis (CFA). Confirmatory factor analysis was performed with the help of SPSS Amos 21 for Windows. The study of the development of this instrument used the acceptance limit of the standardized loading factor or the parameter value of lambda $(\lambda)$ above 0.5 [32].

\section{RESULTS AND DISCUSSION}

\section{Content Validity: Aiken V}

The content validity analysis results using Aiken V showed that the value of the contentvalidity coefficient (Aiken index) on the 16 items 
of the OSEQ questionnaire ranged from 0.83 to 1.00 (see Table 2). The Aiken $\mathrm{V}$ index means that all chef occupational self-efficacy instruments have high validity because they have an Aiken $\mathrm{V}$ index of more than 0.8 [31].

Table 2. The Contents Validity Using Aiken V

\begin{tabular}{lcc}
\multicolumn{1}{c}{ Items } & Aiken Index & Validity \\
\hline EE1 - EE4 & $0.92 \sim 1.00$ & Strong \\
ME1 - ME4 & $0.83 \sim 0.92$ & Strong \\
SP1 - SP4 & $0.92 \sim 1.00$ & Strong \\
EC1 - EC4 & $0.92 \sim 1.00$ & Strong \\
\hline
\end{tabular}

Note: EE1-EE4= items of enactive experience; ME1-ME4= items of model experience; SP1-SP4 = items of social persuasion; EC1-EC4 = items of emotional state.

\section{Pilot Testing with Small Samples}

Furthermore, the OSEQ questionnaire was tested on 59 vocational students of the Culinary Arts Department to see its validity and reliability. The Pearson product-moment correlation test results showed that the chef occupation self-efficacy instrument was valid and reliable. Table 3 shows that all instrument items have a significant correlation $(r=0.387$ $r=0.785$ ) [33]. Distribution of occupational selfefficacy instrument items on each indicator, namely enactive experience (4 points), model experience (4 points), verbal or social persuasion (4 points), and emotional conditions (4 points).

Table 3. Validity Test of Occupational Self-Efficacy Instruments (16 items)

\begin{tabular}{lcc}
\hline \multicolumn{1}{c}{ Items } & $\begin{array}{c}\text { Pearson } \\
\text { Correlation }\end{array}$ & Sig. (2-tailed) \\
\hline EE1 - EE4 & $0.407^{* *} \sim 0.761^{* *}$ & $0.000 \sim 0.001$ \\
ME1 - ME4 & $0.387^{* *} \sim 0.674^{* *}$ & $0.000 \sim 0.001$ \\
SP1 - SP4 & $0.703^{* *} \sim 0.785^{* *}$ & 0.000 \\
EC1 - EC4 & $0.510^{* *} \sim 0.743^{* *}$ & 0.000 \\
\hline$* *$. Correlation is significant at the 0.01 level (2-tailed). \\
*. Correlation is significant at the 0.05 level (2-tailed).
\end{tabular}

Meanwhile, the entire chef occupational self-efficacy instrument also showed a Cronbach's Alpha value of 0.894; this value is above 0.700 and means that the instrument is considered reliable to measure vocational students' perceptions of their self-efficacy work as a chef.

\section{Construct Validity of OSEQ}

The occupational self-efficacy of cooking ability in this study is an endogenous latent variable. It is formed by several observable variables (manifest variables or indicator variables), which include experiences of active mastery, model experience, verbal/social persuasion, and emotional conditions. The total items of the questionnaire totaled 16 statements consisting of four items of enactive experience, four items of model experience, four items of verbal or social persuasion, and four items of emotional condition. The results of the CFA test on the occupational self-efficacy instrument of cooking ability are shown in Figure 1. The estimation results of the model measurements in Figure 1 using the Maximum Likelihood estimation on Amos show the results of the model fit are good enough.

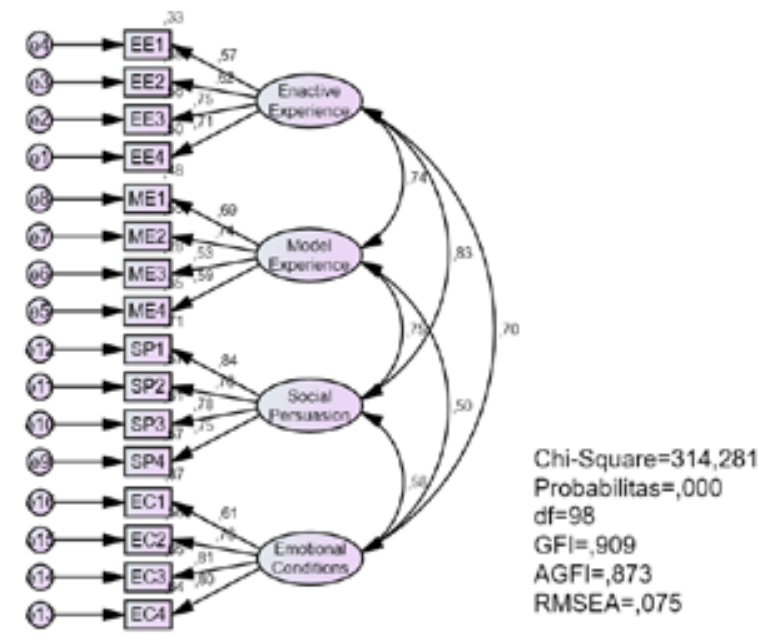

Figure 1. Measurement Model of the Occupational Self-Efficacy Instrument for Cooking Performance

The model fit test in Table 4 shows the criteria of Cmin/df, GFI, AGFI, RMSEA, RMR, TLI, CFI, and NFI, giving conformity indexes that correspond to the recommended limits. However, the Chi-square and probability level criteria indicate that the requirements are not fit because they exceed the recommended limits. In 
total, eight indices show the fit model. Thus, it can be concluded that the measurement model in the construct of endogenous self-efficacy variables in the profession of chef has a good fit.

Table 4. Model Fit Index on Occupational Self-Efficacy Instruments for Cooking Performance

\begin{tabular}{|c|c|c|c|}
\hline $\begin{array}{l}\text { Goodness } \\
\text { of Fit } \\
\text { Measure }\end{array}$ & Index Value & Cut off-value & Note \\
\hline df & 98 & & \\
\hline $\begin{array}{l}\text { Chi-square } \\
\text { of estimate } \\
\text { model }\end{array}$ & 314.281 & $<2 \mathrm{df}$ & $\begin{array}{l}\text { Model } \\
\text { not fit }\end{array}$ \\
\hline $\begin{array}{c}\text { Probability } \\
\text { level }\end{array}$ & 0.000 & $>0.05$ & $\begin{array}{l}\text { Model } \\
\text { not fit }\end{array}$ \\
\hline $\mathrm{Cmin} / \mathrm{df}$ & 3.207 & $\leq 5$ & $\begin{array}{l}\text { Model } \\
\text { fit }\end{array}$ \\
\hline $\begin{array}{c}\text { Goodness } \\
\text { of Index } \\
\text { (GFI) }\end{array}$ & 0.909 & $\begin{array}{c}\text { GFI } \geq 0.9= \\
\text { good fit; } 0.8 \leq \\
\text { GFI }<0.9= \\
\text { marginal fit }\end{array}$ & $\begin{array}{c}\text { Model } \\
\text { fit }\end{array}$ \\
\hline $\begin{array}{l}\text { Adjusted } \\
\text { Goodness } \\
\text { of Index } \\
\text { (AGFI) }\end{array}$ & 0.873 & $\begin{array}{c}\text { AGFI } \geq 0.9= \\
\text { good fit; } 0.8 \leq \\
\text { AGFI }<0.9= \\
\text { marginal fit }\end{array}$ & $\begin{array}{l}\text { Margi } \\
\text { nal fit }\end{array}$ \\
\hline RMSEA & 0.075 & $\leq 0.08$ & $\begin{array}{c}\text { Model } \\
\text { fit }\end{array}$ \\
\hline RMR & 0.037 & $<0.05$ & $\begin{array}{c}\text { Model } \\
\text { fit }\end{array}$ \\
\hline $\begin{array}{l}\text { Tucker- } \\
\text { Lewis } \\
\text { Index (TLI) }\end{array}$ & 0.905 & $\begin{array}{c}\text { TLI } \geq 0.9= \\
\text { good fit; } 0.8 \leq \\
\text { TLI }<0.9= \\
\text { marginal fit }\end{array}$ & $\begin{array}{c}\text { Model } \\
\text { fit }\end{array}$ \\
\hline $\begin{array}{l}\text { Comparativ } \\
\text { e Fit Index } \\
\quad(\mathrm{CFI})\end{array}$ & 0.923 & $\begin{array}{c}\mathrm{CFI} \geq 0.9= \\
\text { good fit; } 0.8 \leq \\
\mathrm{CFI}<0.9= \\
\text { marginal fit }\end{array}$ & $\begin{array}{c}\text { Model } \\
\text { fit }\end{array}$ \\
\hline $\begin{array}{l}\text { Normo Fit } \\
\text { Index (NFI) }\end{array}$ & 0.892 & $\begin{array}{c}\text { NFI } \geq 0.9= \\
\text { good fit; } 0.8 \leq \\
\text { NFI }<0.9= \\
\text { marginal fit }\end{array}$ & $\begin{array}{l}\text { Margi } \\
\text { nal fit }\end{array}$ \\
\hline
\end{tabular}

Meanwhile, the results of the standardized loading factor value points for each indicator are shown in Table 5. The statement items for each occupational self-efficacy measurement indicator have a parameter value of $\lambda$ (lambda) above 0.5 . This result means that overall, 16 items are declared valid to measure students' culinary perceptions of occupational selfefficacy on their cooking performance. Besides, these results indicate that occupational selfefficacy on cooking performance can be explained significantly together by indicators of enactive experience, model experience, social persuasion, and emotional states.

Table 5. Standardized Regression Weights on Occupational Self-Efficacy Instruments on Cooking Performance

\begin{tabular}{ccccc}
\hline & Path & Estimate & $\begin{array}{c}\text { P- } \\
\text { value }\end{array}$ \\
\hline EE1 - EE4 & $<---$ & $\begin{array}{l}\text { Enactive } \\
\text { experience }\end{array}$ & $0.575 \sim 0.749$ & $* * *$ \\
ME1 - ME4 & $<---$ & $\begin{array}{l}\text { Model } \\
\text { experience }\end{array}$ & $0.527 \sim 0.741$ & $* * *$ \\
SP1 - SP4 & $<---$ & $\begin{array}{l}\text { Social } \\
\text { persuasion }\end{array}$ & $0.752 \sim 0.844$ & $* * *$ \\
EC1 - EC4 & $<---$ & $\begin{array}{l}\text { Emotional } \\
\text { condition }\end{array}$ & $0.610 \sim 0.805$ & $* * *$ \\
& & \\
\hline$* * *$ The p-value is very small (less than 0.001)
\end{tabular}

\section{Reliability Test}

The results of the construct reliability test on the chef occupational self-efficacy instrument are shown in Table 6 . These results indicate that all indicators, including enactive mastery experience, model experience, social persuasion, and emotional conditions, have a construct reliability value above 0.7 . Indicators of social persuasion have the largest value of construct reliability than other indicators. Meanwhile, the lowest construct reliability value is shown in the model experience indicator. Thus, chef occupational self-efficacy can be explained or measured by indicators of active mastery experience, model experience, social persuasion, and emotional states.

Table 6. Reliability of the OSEQ of Cooking Performance Measurement Model

\begin{tabular}{lcl}
\hline \multicolumn{1}{c}{ Indicator } & $\begin{array}{c}\text { Construct } \\
\text { Reliability }\end{array}$ & Note \\
\hline Enactive Experience & 0.854 & Reliable \\
Model Experience & 0.816 & Reliable \\
Social Persuasion & 0.907 & Reliable \\
Emotional Condition & 0.900 & Reliable \\
\hline
\end{tabular}

The results of this study confirm that culinary students' perceptions of occupational self-efficacy on cooking skills can be measured 
using indicators of enactive experience, experience models, social persuasion, and emotional conditions. This finding is relevant to the questionnaire developed by Zelenak [29]. Zelenak [29] developed a self-efficacy questionnaire in music performances that involved indicators of enactive experience, experience models, social persuasion, and emotional conditions. This study reveals that social persuasion has a higher reliability value than other indicators and is followed by emotional conditions indicators. This emotional state explains how students enjoy and believe in their cooking skills, career choices, and the quality of their processed products.

Social persuasion indicators have the highest reliability value to explain the selfefficacy of a chef's occupation. Social persuasion indicators are assessments and opinions of others and their influence on individual decisionmaking processes. In this study, this indicator reports students 'perceptions about the verbal assessment of the cooking ability of friends, the verbal assessment of the cooking ability of the family, the verbal assessment of the cooking ability of the teacher, and other people's expectations of the students' cooking ability. The acquisition of the reliability value of the chef occupational self-efficacy indicator in the second place is an emotional condition. This indicator explains students' enjoyment and confidence in their cooking skills, career choices, and the quality of their processed products.

The third highest reliability value is the enactive experience indicator. Enactive experience refers to the belief gained in one's past success or failure in cooking skills. According to Bandura [2] and Schunk and Usher, it is an achievement that has been personally experienced and proven. In the context of this study, the indicators of active experience explain students' perceptions of positive cooking experiences, cooking practice experiences, and achievement of their cooking skills. Finally, the indicator with the lowest reliability gain is the model experience. This indicator refers to students' beliefs gained through observing others for their success or failure. In this context, the model experience indicator reports students' perceptions of the cooking learning experience and compares cooking skills from various sources, including media, friends, and teachers. Overall, the four indicators have been tested for validity and reliability. Thus, chef occupational self-efficacy can be explained or measured by indicators of active mastery experience, model experience, social persuasion, and emotional states.

\section{CONCLUSION}

The results of this study indicate that occupational self-efficacy on cooking ability can be explained significantly together by indicators of active mastery experience, model experience, social persuasion, and emotional states. CFA analysis revealed that 16 items of the occupational self-efficacy questionnaire cooking abilities were declared valid. The occupational self-efficacy questionnaire of cooking ability consisted of four items of enactive experience, four items of model experience, four items of verbal or social persuasion, and four items of emotional condition. The results of this study have implications for hospitality industry practitioners to measure the cooking abilities of chefs. Besides, this questionnaire can be used to evaluate the achievements of the culinary students' cooking competencies. Future research that can be proposed to complement the shortcomings of this study is the measurement of occupational self-efficacy on cooking performance from a chef's perspective.

\section{ACKNOWLEDGMENT}

We thank the Ministry of Education and Culture of the Republic of Indonesia for supporting this research funding. Also, we appreciate all the Culinary Art State Vocational School in the Yogyakarta Special Region who have been involved as respondents in this study. 


\section{REFERENCES}

[1] F. Luthans, K. W. Luthans, and B. C. Luthans, "Positive psychological capital: Beyond human and social capital," Bus. Horiz., vol. 47, pp. 45-50, 2004.

[2] A. Bandura, "Self-efficacy: Toward a unifying theory of behavioral change," Psychol. Rev., vol. 84, no. 2, pp. 191215, 1977.

[3] A. Bandura, Social Foundations of Thought and Action. Englewood Cliffs, NJ: Prentice Hall, 1986.

[4] T. Seifert, "Understanding student motivation," Educ. Res., vol. 46, no. 2, pp. 137-149, 2010, doi: $10.1080 / 0013188042000222421$.

[5] M. Yusuf, "The Impact of self-efficacy, achievement motivation, and selfregulated learning strategies on students' academic achievement," in Procedia Social and Behavioral Sciences, 2011, vol. 15, pp. 2623-2626, doi: 10.1016/j.sbspro.2011.04.158.

[6] M. Çavuş and A. Kapusuz, "Psychological capital: Definition, components and effects," $B r . J$. Educ. Soc. Behav. Sci., vol. 5, pp. 244-255, 2015.

[7] A. Bandura, C. Pastorelli, C. Barbaranelli, and G. V. Caprara, "Selfefficacy pathways to childhood depression," J. Pers. Soc. Psychol., vol. 76, no. 2, pp. 258-269, 1999.

[8] A. D. Stajkovic and F. Luthans, "Social cognitive theory and self efficacy: Going beyond traditional motivational and behavioral approaches," Organ. Dyn., vol. 26, no. 4, pp. 62-74, 1998.

[9] A. Bandura, Self-Efficacy: The Exercise of Control. New York: Freeman, 1997.

[10] A. S. Md. Yunus and W. Z. Wan Ali, "Metacognition and motivation in mathematical problem solving," Int. J. Learn., vol. 15, no. 3, pp. 121-132, 2009.

[11] T. Rigotti, B. Schyns, and G. Mohr, "A short version of the occupational self- efficacy scale: structural and construct validity across five countries," $J$. Career Assess., vol. 16, no. 2, pp. 238-255, May 2008, doi: 10.1177/1069072707305763.

[12] A. Hirschi and V. K. Jaensch, "Narcissism and career success: Occupational self-efficacy and career engagement as mediators," Pers. Individ. Dif., vol. 77, pp. 205-208, 2015, doi: https://doi.org/10.1016/j.paid.2015.01.00 2.

[13] F. Fallatah, H. K. S. Laschinger, and E. A. Read, "The effects of authentic leadership, organizational identification, and occupational coping self-efficacy on new graduate nurses' job turnover intentions in Canada," Nurs. Outlook, vol. 65 , no. 2 , pp. 172-183, 2017, doi: https://doi.org/10.1016/j.outlook.2016.1 1.020 .

[14] F. Çetin and D. Aşkun, "The effect of occupational self-efficacy on work performance through intrinsic work motivation," Manag. Res. Rev., vol. 41, no. 2, pp. 186-201, Jan. 2019, doi: 10.1108/MRR-03-2017-0062.

[15] E. Liu and J. Huang, "Occupational selfefficacy, organizational commitment, and work engagement," Soc. Behav. Personal. An Int. J., vol. 47, no. 8, pp. 17, 2019.

[16] A. Klaeijsen, M. Vermeulen, and R. Martens, "Teachers' innovative behaviour: the importance of basic psychological need satisfaction, intrinsic motivation, and occupational selfefficacy," Scand. J. Educ. Res., vol. 62, no. 5, pp. 769-782, Sep. 2018, doi: 10.1080/00313831.2017.1306803.

[17] M. E. Paggi and D. S. Jopp, "Outcomes of occupational self-efficacy in older workers," Int. J. Aging Hum. Dev., vol. 80, no. 4, pp. 357-378, Apr. 2015, doi: $10.1177 / 0091415015607640$.

[18] M. D. Líbano, S. Llorens, M. Salanoval, and W. B. Schaufeli, "About the dark and bright sides of self-efficacy: 
workaholism and work engagement," Span. J. Psychol., vol. 15, no. 2, pp. 688701, 2012, doi: doi:10.5209/rev_ SJOP.2012.v15.n2.38883.

[19] M. Salanova, S. Llorens, and W. B. Schaufeli, "'Yes, I can, I feel good, and I just do it!' On gain cycles and spirals of efficacy beliefs, affect, and engagement," Appl. Psychol., vol. 60, no. 2, pp. 255285, 2011, doi: 10.1111/j.14640597.2010.00435.x.

[20] C. M. Brotheridge and A. A. Grandey, "Emotional labor and burnout: Comparing two perspectives of "people work'.," J. Vocat. Behav., vol. 60, no. 1, pp. 17-39, 2002, doi: 10.1006/jvbe.2001.1815.

[21] D. Guglielmi, S. Simbula, W. B. Schaufeli, and M. Depolo, "Self-efficacy and workaholism as initiators of the job demands-resources model.," Career Dev. Int., vol. 17, no. 4, pp. 375-389, 2012, doi: $10.1108 / 13620431211255842$.

[22] K. Kafetsios and L. A. Zampetakis, "Emotional intelligence and job satisfaction: Testing the mediatory role of positive and negative affect at work.," Pers. Individ. Dif., vol. 44, no. 3, pp. 712-722, 2008, doi: 10.1016/j.paid.2007.10.004.

[23] E. L. Usher and F. Pajares, "Sources of self-efficacy in mathematics: a validation study," Contemp. Educ. Psychol., vol. 34, pp. 89-101, 2009, doi: 10.1016/j.cedpsych.2008.09.002.

[24] D. H. Schunk and E. L. Usher, "Social Cognitive Theory and Motivation," in The Oxford Handbook of Human Motivation, New York: Oxford University Press, 2012, pp. 13-27.

[25] K. S. Hendricks, "The sources of selfefficacy: Educational research and implications for music," Natl. Assoc. Music Educ., vol. 35, no. 1, pp. 32-38, 2016, doi: $10.1177 / 8755123315576535$.
[26] C. S. Dweck, Self-theories: Their role in motivation, personality, and development. Philadelphia, PA: Psychology Press, 2000.

[27] S. E. Pitts, J. W. Davidson, and G. E. McPherson, "Models of success and failure in instrumental learning: Case studies of young players in the first 20 months of learning," Bull. Counc. Res. Music Educ., no. 146, pp. 51-69, 2000.

[28] D. Cioffi, "Sensory awareness versus sensory impression: Affect and attention interact to produce somatic meaning," Cogn. Emot., vol. 5, no. 4, pp. 275-294, Jul. 1991, doi: 10.1080/02699939108411041.

[29] M. Zelenak, "Self-Eficacy in Music Performance: Measuring the Sources among Secondary School Music Students," University of South Florida, 2011.

[30] L. R. Aiken, "Three coefficients for analyzing the reliability and validity of ratings.," Educ. Psychol. Meas., vol. 45, no. 1, pp. 131-142, 1985, doi: 10.1177/0013164485451012.

[31] H. Retnawati, Analisis Kuantitatif Instrumen Penelitian. Yogyakarta: Parama Publishing, 2016.

[32] I. Ghozali, Structural Equation Models: Concepts and Applications with the AMOS 24 Bayesian SEM Update Program (Indonesian Version), Edisi 7. Semarang: Badan Penerbit Universitas Diponegoro, 2017.

[33] J. F. Hair, W. C. Black, B. J. Babin, and R. E. Anderson, Multivariate Data Analysis: A Global Perspective, 7th. Upper Saddle River: Pearson Prentice Hall, 2010. 